\title{
The Global Situation Demands More Research and Dissemination in 2019
}

\author{
Øyvind Ravna* \\ UiT The Arctic University of Norway, Tromse, Norway
}

2018 has been a demanding year internationally. The relationship between East and West has become colder and more complicated. Among other things we see increased military activity in the Arctic as well as unclear military constellations in the Middle East and armed confrontations between Russia and Ukraine in the Azov Sea. Also, the relationship between the United States and its allies in Europe has become more difficult. An unpredictable US foreign policy makes European countries uncertain whether they can rely on the US security guarantees. Nor is the trade war between the United States and China a good contribution to world peace and stability. And mass cross-border migrations are becoming increasingly common around the world in Asia, Africa, Europe and now the Americas.

The effects of climate change, which are becoming more and more visible, is another threatening factor for world community and global stability. Nevertheless, the world's leading politicians seem to have difficulty in entering into effective agreements that contribute to limiting emissions and reducing the harmful effects of climate change.

The global polarization has contributed to a weakening of the United Nation's authority and its international treaties at a time they rather should be strengthened. This applies both to the obligations of environmental agreements and human rights conventions. However, this does not make the UN's position as a common arena for solving international conflicts less important.

The more demanding global situation poses new demands and challenges on research and dissemination aimed at international conflict issues - not least related to the Arctic. Cross-border research and academic cooperation are a counterweight to the more polarized world and increasing climate threat we have seen more clearly in 2018. Here, academic communities, universities and individual researchers all have an important task and responsibility.

\footnotetext{
^Correspondence to: Øyvind Ravna, email: oyvind.ravna@uit.no

(C) 2019 Øyvind Ravna. This is an Open Access article distributed under the terms of the Creative Commons Attribution-NonCommercial 4.0 International License (https://creativecommons.org/licenses/by-nc/4.0/), allowing third parties to share their work (copy, distribute, transmit) and to adapt it, under the condition that the authors are given credit, that the work is not used for commercial purposes, and that in the event of reuse or distribution, the terms of this license are made clear.
} 


\section{Øyvind Ravna}

The situation also challenges academic journals, publishers and others who disseminate research results and new knowledge. It is a challenge that Arctic Review on Law and Politics takes seriously. The journal has never before published so many original articles in one year as in 2018. In total, 18 manuscripts passed a strict peer-review process, all evaluated carefully by two independent peers. The articles cover topics such as military security issues in the Arctic, through preparedness systems in the High North and cooperation between universities and industry in northern regions, to conflicts related to tourism and consultation obligations to indigenous peoples. By the end of the year, the journal had published four articles in two consecutive series edited by guest editors, highly relevant to answer the challenges mentioned above. The first series analyses the impact of climate change on the management of marine resources, while the second examines how current Russian-Western relations affect cooperation in the Arctic. Both series will continue with additional articles in 2019 under the same guest editors.

Arctic Review on Law and Politics not only achieved a peak in the number of original articles published in 2018, it also received a record number of manuscripts last year. The increasing interest in Arctic Review can be explained by the fact that after eight years, the journal has become an established periodical, able to meet its obligation to publish new knowledge within social sciences and law related to the Arctic and Northern regions. That the journal publishes these original articles Open Access, thus reaching all the corners of the world, also explains the growing interest. This is underlined by the fact that the journal has contributors from most countries with territories bordering the Arctic.

In addition, the journal has been fortunate to have well-qualified national editors and recently, well-qualified guest editors also (see below) - all of whom have contributed to bringing in excellent, topical manuscripts. Not only academic quality and scope have increased, the journal has also broadened its range of content, particularly on security issues.

Despite the increasing quantity of well-written, timely research articles, the journal was recently demoted by the Norwegian Register for Scientific Journals, Series and Publishers. After years of being ranked as a level 2 publication channel among Norwegian journals of jurisprudence, Arctic Review on Law and Politics was placed in the level 1 category in the fall of 2017 with effect from January 1, 2019. It is our understanding that this change is not reflective of Arctic Review's scientific quality, peer-review procedures or content relevance; it is simply a result of the fact that only a prescribed number of journals can be ranked at level 2 within the system. Furthermore, the editors regard this as a temporary ranking, and we will work actively to return Arctic Review to level 2-standing among Norwegian academic journals.

At the beginning of 2019, Arctic Review is pleased to present two original, peerreviewed articles. Rasmus Kløcker Larsen of Stockholm Environment Institute and Kaisa Raitio of Swedish University of Agricultural Sciences examine the duty to consult, a very current issue in Sweden as well as other countries with indigenous peoples. In Norway, for example, the government has recently introduced a bill to 
legislate the state's consultation obligations. So far, this is not the case in Sweden. In the article Implementing the State Duty to Consult in Land and Resource Decisions: Perspectives from Sami Communities and Swedish State Officials, the authors explore the ability of Swedish state actors to discharge the duty to consult, based on lessons existing duties set out in legislation dealing with minorities and indigenous people. They argue that if state duties are to promote the intended intercultural reconciliation, new measures are needed to ensure that the duties re-fulfilled. In addition, sectoral resource regulations need to be amended to consistently refer to the duties set out in minority law or a potential new bill on the duty to consult. The authors recommend that state agencies and Sámi communities develop consultation routines for the relevant sectors together.

Olav Schram Stokke, Department of Political Science, University of Oslo, and Arild Moe, Fridtjof Nansen Institute, Lysaker, Norway, explore another current topic. In the article Asian Countries and Arctic Shipping: Policies, Interests and Footprints on Governance, the authors consider the advantages of Arctic sea routes over the Suez and Panama alternatives in light of the political, bureaucratic and economic conditions surrounding shipping and shipbuilding in China, Japan and the Republic of Korea. They present several interesting findings, among others that policy documents, especially in Japan and Korea, indicate realism rather than optimism concerning Arctic sea routes. They also find that policymakers show greater caution than analysts and point to a clear tendency of rising industry-level caution and restraint in all three countries, reflecting a growing sensitivity to the economic and political risks associated with the Arctic routes.

Finally, I would like to thank the 2018 editorial team for their excellent work on behalf of the journal during the year that has passed. The team consisted of the guest editors Noor Johnson, Greg Poelzer, Elise Johansen and Helge Blakkisrud, the national editors Nigel Bankes (Canada), Timo Koivurova (Finland), Hanne Petersen (Denmark/Greenland), Vladimir Kryazhkov (Russia), Eva Carina Keskitalo (Sweden), Oran R. Young (United States) and Gudmundur Alfredsson (Iceland), the political science editor Njord Wegge, the associate editors Natalia Loukacheva and Margherita Paola Poto, all of our anonymous peer-reviewers and, not least, the journal manager Katia Stieglitz. A particular thanks to Nigel, Timo, Njord and Katia for great effort!

I would also like to thank all those who have submitted well-written and wellresearched manuscripts, book reports and other contributions to Arctic Review during last year. I am also pleased that, after a tender process at the end of last year, the Nordic Open Access Scholarly Publishing (NOASP) division of Cappelen Damm Akademisk will continue to be the journal's publisher.

Lastly, I hope that the journal receives at least as many quality manuscripts in 2019 as in 2018 - so that we will be able to meet our goal of publishing plenty of new, good northern research. A Happy New Year to all readers and Arctic researchers!!

Øyvind Ravna

Editor-in-chief 